\title{
Politics, Power and Public Policy-making: A Response to Karen Baehler
}

\section{Robert Gregory}

\section{T alking past each other}

Karen Baehler's (2005) interpretation of my articles (G regory, 1998, 2002, 2004) indicates that we are largely talking past each other. I believe we make a fundamentally different assumption about the nature of politics in what she refers to as 'a healthy democratic polity' (p.3), and about the nature of a capitalist political-economic system. Whereas Baehler acknowledges the importance of the political dimensions of policy analysis and public policymaking, I believe that these elements are more than just important but essential, omnipresent, ineluctable and conclusive in shaping public policy and its effects.

At the heart of Baehler's (2005, p.3) critique of my less sanguine views about rationality in public policy-making is her argument - drawing on theoretical input from other theorists - that the most appropriate role for the policy analyst in a liberal democracy is 'public argument advising'. A public argument is 'a coherent set of propositions that lead from premises to a policy conclusion', and 'presents the case for a particular policy choice, including reasons why the policy should be favoured'. It 'presents the kind of policy case that citizens will recognise as legitimate and worthy of discussion, even if they disagree with the premises and conclusions'. Baehler illustrates her advocacy of public argument with reference to two examples from my cited articles - the American government's decision to invade Iraq in 2003, and the application in New Zealand of 'Rogernomics' in the 1980s.

\section{Moral dilemmas for the policy adviser on I raq}

The essence of my argument regarding the role of a policy analyst advising George W. Bush and his colleagues in regard to the decision to invade Iraq was that formal policy analysis (in that case, employing the techniques of 'intervention logic') confronts the paradox of analytical rigour and political relevance. Analysis can be rigorous (but of course it sometimes/ often is not) but it may also be rigorously irrelevant (to actual policymaking) if it does not speak constructively to the agendas that are driving decision makers. These agendas, as Baehler fully acknowledges, may be overt or covert. That is, they may be expressible as the sort of public arguments she advocates, with which people may agree or disagree, or they may not be expressible as such, since many if not a majority of people would find them obviously unacceptable, if not offensive - if they were made aware of them. In the case of the invasion, public debate could legitimately swirl around the acceptability of such justifications as 'regime change' and/ or 'weapons of mass destruction', or 'bringing democracy to Iraq'. But strategic control of Iraqi oil resources or (as Baehler puts it, ) 'exacting revenge for old Bush family grievances or distributing lucrative postwar reconstruction contracts to business cronies' (p.4) would hardly be viable public justifications.

Baehler argues that:

The best of Bush's defence and foreign policy advisers under the circumstances would have been aware of these possible motivations but also kept their distance. They would have focused ex dusively on thek inds of arguments that could bevetted in public. They would have constructed these arguments, tested them, and presented their strengths and weaknesses, in the full knowledge that their adviœ was unlik ely to influenœ policy choiø but was nonetheless an important part of the historical record (pp.4-5, emphasis added).

Would not this hypothetical policy adviser/ analyst face a compelling moral choice - to be willingly complicit in an act of public deception (since he or she would know the real reasons for the decision to invade), or to 
refuse to be complicit in decisions that they might even think constituted war crimes? If not, then the policy adviser's moral horizons seem purely Tennysonian 'Ours not to reason why, ours but to do and die' except that in this case thousands of others have been doing the dying. If the 'professionalism' of policy analysts is to be gauged (at least in part) by their dutiful willingness to serve, no matter how duplicitously, the political interests of their sponsors then we should, I believe, be extremely wary of constructing such 'professional' role expectations. The distinction between 'spin doctoring' and 'public argument advising' may be a very fine one in many cases.

G overnment officials as individuals must retain, even nurture, a capacity for personal reflective judgement, even as they work in contexts and in roles which by their nature insidiously limit that capacity. As Brian Chapman (1959, p.275) observed:

Neutrality in public office tends in the end to moral corruption. If all governments are to be served with equal impartiality and loyalty there are no grounds at all for criticizing the $\mathrm{German}$ official who served Hitler to the best of his ability. In any profession other than government such people would be regarded as dangerous cynics or weaklings.

So what should the policy analyst actually do? To ask this question is to presuppose that there is some clear course of action that an adviser ought to take. However, any such clarity can be found only in the adviser's own mind, cannot necessarily be prescribed in some code of professional conduct, and will depend heavily on the circumstances of each case. It is ultimately a matter of individual moral choice. In some instances advisers might resign and publicly blow the whistle - thus making 'the undiscussable discussable' - while in others they might decide to do what the decision makers want and say nothing to anyone, or they make choices that lie somewhere in between. (The first option has the great virtue of leaving its mark on the public record for historical consideration.)

\section{Public argument advice in the age of 'Rogernomics': stellar or sterile?}

Baehler rejects my argument (G regory, 1998) that especially between 1984 and 1987 New Zealand's liberal democracy became highly technocratic, its main features being policy-making by an elite group which determinedly 'crashed through' political institutions and processes, the better to implement economic policies that were profoundly ideological yet publicly paraded as being 'scientifically' rigorous. Instead, she claims that the policy advice given to D avid Lange's government was 'a stellar example of public argument advising' (p.5).

She concedes that key planks of the policy agenda were rushed through Parliament in urgency, and that many discussions were held behind closed doors. But, 'the advice itself was eminently presentable and, if presented, would have sparked a healthy, vigorous public debate in almost any other democratic country with a more heavily contested political environment and longer experience with ideas of deregulation, privatisation, and rolling back the state' (p.5, emphasis added).

The conditional statement here - 'if presented' - is surely contradictory. How can an example of 'public argument advising' be considered 'stellar', if in fact there is little or no public (as distinct from private discussions among the elite) argument that results from it? If, in other words, the advice is democraticallysterile? Baehler lauds the 'superb political skills of the people driving the agenda and their ability to wield the strong executive powers granted by the pre-MMP, first-pastthe post pariamentarysystem' (p.6). But thisisto praise them for theabilities to close off, rather than to foster, public debate on the policy advice which they offered and/ or received.

It is true that much of the policy advice in those heady times was made publicly available, efficiently and enthusiastically - notably the briefing papers to ministers, E conomic $M$ anagement (1984) and $G$ overnment $M$ anagement (1987). Yet it was ironic that the scope for public discussion of this material was severely constrained, by the political strategy of 'crashing through'. Contrary to what Baehler asserts, there were at the time (and have been since) some academics who were publicly critical of what was happening, but I would be very surprised if their concems were sought out and listened to by those in the policy-making inner circle. O nly the views of cheer-leaders were listened to, and they were not needed in any case.

As I noted in my original article, one of the people driving the agenda, SirG eoffrey Palmer (1992, p. 13), later observed:

What has developed in New Zealand is something of a disjunction between the 
policymaking process and the political process. The decision-makers are a select few politicians who decide things, not on the basis of what the political process of representative democracy tells them, but on the basis of what some varieties of economic or policy theory tell them.

While I would reject the implication that 'the policymaking process' (whatever that is) is not itself political I would agree that Palmer here offers a sketch of the strong technocratic tendencies that emerged during the 1980s, and which - by popular demand - were only really rolled back by the push for a system of proportional representation, the better to bring politics more squarely back into this central arena of public policy argument and deliberation. If the years of 'Rogernomics' constitute a 'stellar example of public argument advising', then I for one would hate to see a bad case of it.

Baehler goes on to say that, 'Had the election of 1990 gone differently, yet more streams of thinking could have been incorporated [in the advisers' "policy architecture"], including perhaps a more social democratic approach to social policy, which, combined with the economic and state sector reforms, would have constituted New Z ealand's unique brand of thirdway governance' (p.6). A principal reason why the 1990 election did not go differently was that the Labour government had imploded by then - largely because of overt ideological and political fissures, which could not be surmounted by any appeal to the virtues of public argument advice. In fact, it is worth noting that both the Lange government which came into office in 1984 and the Bolger administration that was elected in 1990 pursued radical economic and social policies, respectively, which had not really been foreshadowed in their election campaigns. There is little or no evidence that the drastic social welfare policies revealed in Ruth Richardson's 'Mother of All Budgets' in 1991 were widely anticipated by the New Zealand electorate. While the policy advice which lay behind them might also be regarded as a 'stellar' case of public argument advising, the overwhelming emphasis - as with 'Rogernomics' was on the advising rather than the public argument. Certainly strong public debate occurred after the policies had been announced and pursued, and was a major factor in Richardson being dropped as finance minister after the National Party had won the 1993 election. But the experiences of both the 1980s and early 1990s were crucial in the subsequent moves, culminating in the adoption of the MMP electoral system, to bring parliamentary politics back to the centre of the public policy process.

Some may complain that as a consequence $\mathrm{New}$ Zealand governments now lack the flexibility of response that was more readily available to them under first-past-the-post, but others - myself among them would value more highly the democratic constraints that have now been applied to the exercise of power by the political executive. Is it not inconceivable that the need to bargain and negotiate the security of parliamentary votes of confidence and supply may carry more democratic virtue than public argument advice formulated by policy analysts locked in bureaucratic ivory towers?

\section{Power and reason}

I agree with Baehler that the concept of 'public argument advising' is a valuable idea in the quest to define a legitimate role for policy analysts in a modern democracy. However, I do not find anything new in it, apart from the terminology itself.

Policy-makers - whether elected politicians, senior public servants, political appointees in ministerial offices, or the policy analysts who inhabit today's departments and ministries - have always engaged in the profoundly political task of crafting coherent public justifications for policy preferences. (E ichbaum and Shaw argue in this issue of Policy Q uarterly that the relationships among these different players are evolving in subtle ways.) But an emergent discipline like public policy gives rise to more and more scholarly activity, and the best of its enduring theoretical insights usually provided by the field's best and earliest luminaries - tend to get recycled in a new vocabulary, and academic effort is invested in developing refinements at the conceptual and theoretical margins. This is no bad thing, as it provides us academics with a style of life to which we feel entitled, and keeps us off the streets, out of harm's way. (Some might say that the only harm involved befalls an unsuspecting public, which bears the brunt of the practical consequences of academic ideas.)

The liberal academic mind-set places great value on the role of reason in public policy-making, and the policy 
analysis industry is predicated on the belief that the application of reason will inevitably lead to 'better policy outcomes'. For my part, however, I am deeply sceptical about the extent to which such reasoning is scientific rather than ideological, and about the extent to which 'reasonable people' can reason together to resolve society's most compelling conflicts of political interest. These conflicts are resolved through the alignment of power relations rather than through the application of analytical skill, and the enduring question in the quest for 'better policy outcomes' remains unaddressed - that is, better for whom? If reason prevailed by the force of logic and scientific conclusiveness in the vast domain of public policy-making then it would hardly matter which political parties were elected to office. (Some would say that it does not matter much in any case.)

In a capitalist political economy a Marxian approach to policy analysis would throw these underlying conflicts, and the nature of economic and political inequality, into much sharper relief than will the mainstream analysis produced in establishment bastions like the Treasury or the Reserve Bank. When analysing, say, the problem of poverty, either locally or internationally, why should such an analytical framework be eschewed? Marx may have placed far too much weight on a class-based interpretation of historical social change, but his insights into the basic conflict between capital and labour in a capitalist international political economy continue to illuminate the structural landscape of poverty and economic inequality.

In regard to the central conflict between capital and labour, it is interesting to contrast political language used at the time of the 1951 industrial conflict in New Zealand and the debate surrounding the introduction of the Employment Contracts Act 40 years later. In the former, the conflict was represented in nakedly honest terms 'smashing the power of the militant unions' or 'fighting for a fair go from exploitative employers', or whatever. In 1991, however, while still lying at the heart of this issue of public policy, it was spoken of by policy elites as if the quest for what was now called labour market flexibility' was essentially a technical issue, around which all 'reasonable' people might sooner or later arrive at a 'reasonable' consensus. One of the crucial changes in the intervening 40 years had been the rise of labour market economics and its impact on the way in which mainstream policy analysis framed, verbalised - and sanitised - the conflict. The thought that policy analysts employing predominantly Marxian frames of reference within which to fashion their 'policy argument advice' could be taken at all seriously within the citadels of policy orthodoxy such as the Treasury and the Reserve Bank, or in the wider community for that matter, is almost laughingly incongruous.

Of course, in a liberal democracy like New Zealand the dominant political economy is grounded in popular legitimacy. What we might call 'mainstream policy analysis' in governmental agencies reflects and supports this concentration of power at the political centre. Few, if any, New Zealanders are clamouring for some sort of neo-Marxian revolution. But this is only to acknowledge the fact that conventional policy analysis largely serves the predominant political forces in society. In so doing it also serves to ensure that the scope of options remains very limited: power is aligned in ways that ensure many alternatives never get onto the policy-making agenda, which was seldom more limited in the 1980s when the policy elite insisted that 'there is no alternative'.

The reason that is most highly valued in government is the 'reasonableness' defined by those in positions of political and economic privilege. Take, for example, the economic and state sector reforms of the 1980s. These were promoted in the name of the public interest, yet why was it that thousands of New Zealanders were severely hurt by these changes while most if not all members of the policy elite that drove them did not themselves bear the financial brunt of the changes, and in some notable cases subsequently did very nicely out of them? The political and ideological character of neoclassical economics (in fact of any brand of economic theory, including Keynesian theory) was confirmed when two of the main policy advisers behind the radical economic changes of the 1980s - D on Brash and Graham Scott - decided to become overtly political players. The former, of course, left his job as G overnor of the Reserve Bank (a position in which he had enjoyed a high degree of 'political independence' yet had delivered a number of profoundly political speeches of neo-liberal policy advocacy) to enter Parliament and later become leader of the National Party, and the latter stood for Parliament in this year's election as a member of ACT. Such overt declarations of political faith by highly influential technocrats - of whatever ideological stripe - 
are rare in New Zealand, and in my view are to be applauded and encouraged. There is, after all, no such thing as political neutrality in policy analysis.

\section{Building capability?}

The old saying that knowledge is power is trite, and it is far less persuasive than the recognition that it is power that generally governs, not knowledge. O nly massive shifts in power alignments, domestically and internationally, would open up real possibilities for 'solving' problems of world poverty, not a further burgeoning of the policy analysis industry (or rock concerts organised in the name of Bob G eldof). What is commonly overlooked is that one person's 'problem' is another's 'solution', and reasoned argument will usually do little to change that. (Years ago, in New Zealand two or three people out of work constituted an unemployment problem. Then from the mid-1970s increasing levels of structural unemployment became a 'problem' mainly for those who were out of work, while in more recent times there has emerged the 'rational' argument that there is a 'natural level of unemployment'. As if political, social and economic relations in society are somehow shaped by general laws analogous to those which determine the physical world.)

The current fad called 'evidence-based policy' is the latest attempt to fudge the reality of power relations, and those who buy into it should remember the pitifully symbolic sight of the former American Secretary of State, Colin Powell, presenting 'evidence' to the United Nations in February 2003 of Saddam Hussein's 'weapons of mass destruction'. Even though such an example of power trumping evidence is not typical in common-or-garden policy analysis conducted on matters far less spectacular than criminal aggression against another country, what passes as 'evidence' is itself politically determined, not necessarily in any party partisan sense (although that can be so) but because in public policy-making the 'facts' are always selectively chosen and never speak for themselves.

Consider, for example, Simon Chapple's (2000) critical analysis of the statistical evidence germane to the former 'Closing the Gaps' policy on 'Mäori socio-economic disparity'. ${ }^{1}$ His paper was highly contentious politically, his analysis was strongly contested by other researchers (Alexander and Williams, 2001), and probably no one today can say conclusively what the 'true' evidence actually is. Generally, it is doubtful if there can be any evidence that is politically authoritative by virtue of its manifest conclusiveness, especially in the highly ambiguous arena of social policy (Lindblom and Cohen, 1979). All evidence is politically (and academically) contestable, which is why democratic norms and values should hold sway over technocratic ones.

Whether we know it or not, and whether we like it or not, those of us who research and teach in academic institutions like the School of Government at Victoria University of Wellington and the Australia and New Zealand School of Government (ANZSOG) serve power as much as knowledge. If we do not know it, or do not acknowledge it, we are deceiving ourselves in the name of 'education', or these days in our endeavours to produce 'learning outcomes'. We become less genuinely critical in our thinking, and are less able to see that the public sector 'capability' we seek to help build is not primarily a technical but a political capacity. And we simply become - for the most rational of instrumental reasons - servants of the establishment, though probably well rewarded for our earnest compliance.

Inherent in all policy analysis in a liberal democracy is the tension between the desire to enhance the political dimensions of policy discussion and debate, and at the same time to search for modes of analysis which can better inform such contestation. I refer to this as the relationship between what can perhaps loosely be called 'experiential knowledge', on the one hand, and 'experimental knowledge', on the other. Karen Baehler's promotion of the idea of 'public argument advice' clearly acknowledges this relationship. Where we part company, I believe, and as demonstrated in her belief in the utility of 'intervention logic', is that I would assert the primacy of politics and power, rather than of analytical calculation, in determining winners and losers in the polity - what some others may call, less provocatively, the distribution of policy costs and benefits.

I think this difference is apparent in Baehler's (2005, p.9) sidebar discussion of 'How to Treat Policy Whiplash' the 'effects of sudden policy starts, stops, and reversals' that are borne by public servants and public agencies. This could be expected if the election were to have resulted in a centre-right government replacing the centre-

Chapple criticised the view that socio-economic gaps between Māori and Pākeha were widening, arguing that contrary to popular rhetoric Māori did not share a common experience of disadvantage. 
left one. In her view, 'In addition to producing these stresses, the habit of reverting to previous policies rather than advancing new ideas may indicate stale policy thinking and a lack of continuous improvement in policy formulation.' She advocates that advisers should try to be familiar with the fullest range of possible arguments and ideas in their policy areas and be able to learn from past policies, rather than be 'trapped in ideological stereotypes' or be 'dazzled by the next new policy fashion being marketed as best practice'.

Three cheers for all that. But given the powerful institutional constraints - which may be subsumed under the term 'bureaucratic politics' - that act on policy advisers, we should not underestimate the real difficulties they would face in trying to follow this advice. Notwithstanding this, the metaphor of 'policy whiplash' connotes a strongly negative interpretation of policy change (who thinks of whiplash as being something desirable?), whereas from a political - indeed, democratic - standpoint it may be a great virtue. Although I do not attribute it to Baehler, there could be a suggestion in the idea of 'whiplash' that policy formulated largely by 'experts' - needs a measure of protection against the capricious behaviour of elected politicians. Yet one person's 'whiplash' is another's democratic responsiveness. (Many Mäori would certainly welcome some 'whiplash' on the foreshore and seabed policy.)

It would also be interesting to know how a policy analyst using the tool of intervention logic could build into his or her calculations the consequences of 'whiplash' without at the same time undermining the utility of their analysis. The only way to do it would be to factor in a change in government as a policy 'risk', but the idea of risk in this context must also address the question: a risk for whom? Again, one person's policy risk is another's political opportunity.

\section{Conclusion}

Whether or not there was any sort of general social and political consensus that held together in New Zealand during most of the 1950s (after the 'militant' unions had been dealt to) and 60s, it is certainly true that by the mid-1970s any such consensus was being put under great strain as adverse economic conditions hit home. This situation made underlying conflicts more apparent at the level of everyday politics, and governments' attempts to forge some new social and political agreement were manifest in the efforts of the New Zealand Planning Council. Reasonable people could talk reasonably together. Yet, political power in the form of authoritarian Muldoonism controlled the public policy agenda, and when that was swept aside by a disillusioned electorate, D avid Lange's government quickly cast aside the pretence of consultation and planning, and went for broke in its efforts to impose solutions from above. An autocrat was cast aside in favour of a group of technocrats.

Policy analysis played its role in all of this, especially under the Lange government. But it was the appeal to the authority of theoretical knowledge that carried the day politically, not the theoretical knowledge itself, since it was not produced in a political vacuum. In this way, knowledge - or what passed as knowledge - was given the legitimacy of power.

The trouble with rationalist interpretations of public policy-making is that they fail, continually, to properly acknowledge the centrality of political power. Of course, it is not that an intellectual or practical choice has to be made between the application of social science research, on the one hand, and the exercise of political power, on the other. What is always at issue is the ongoing relationship between the two (Gregory, 1998). The rational wheel of policy analysis is reinvented in various new guises, as if little or nothing is learned from earlier policy nostrums and failed expectations. The worst outcome of this is not so much policy failure (itself a politically subjective term), but the continued tendency to attribute the blame for such failures to politicians, often considered to be obtuse, opportunistic, or plain stupid. For these reasons any adequate education for those whose business it is to apply their intelligence to the quest for 'better' public policy should include an appreciation of the nature of power and politics and how it provides the dynamic of policy choice. Simply acknowledging the importance of politics then proceeding as if it were ultimately decisive simply will not do. I have used here for illustrative purposes a simple reference to one of history's great political and economic thinkers, Karl Marx. But we do not have to be, or be considered to be, Marxists if we acknowledge that one of the great virtues in his writings was to identify squarely the conflictual nature of a capitalist political economy. Call this 'realism', if you like, but if 
those who work in government do not have an adequate understanding of the dynamics of politics and political institutions, and believe that somehow they can be circumvented in the pursuit of rational policy-making, then they will continue to be frustrated.

\section{References}

Alexander, Robert and Williams, John (2001) 'A Critique of "Mäori Socio-Economic D isparity"', N ew Z ealand Population Review, 27(1\&2): 27-35.

Baehler, Karen (2005) 'What are the Limits to Public Service Advising? The "Public Argument" Test', Policy Q uarterly, 1(3): 3-8.

Chapman, Brian (1959) The Profession of G overnment London, G eorge Allen \& Unwin.

Chapple, Simon (2000) 'Mäori Socio-Economic Disparity', Political Scienœ, 52(2): 101-115.

Gregory, Robert (1998) 'New Zealand as the "New Atlantis"', Canberra Bulletin of Public A dministration, 90: 107-112.

Gregory, Robert (2002) 'Political Life is Larger than Intervention Logic', Public Sector, 26(1): 4-7.

Gregory, Robert (2004) 'Political Life and Intervention Logic: Relearning Old Lessons?' International Public Management Journal, 7(3): 299-315.

Lindblom, Charles and Cohen, David (1979) U sable Knowledge: Social Science and Social Problem Solving New Haven, Yale University Press.

Palmer, G eoffrey (1992) N ew Z ealand's C onstitution in Crisis Dunedin, John McIndoe.
Robert Gregory is an Associate Professor of Public Policy and Administration in the School of Government at Victoria University of Wellington. His research interests include state sector reform, issues of accountability and responsibility in government, and public policy making theory. 